\title{
O ÔNUS DA CIVILIZAÇÃO: HISTERIA E CIVILIZAÇÃO NAS TESES MÉDICAS BRASILEIRAS (1838 - 1890)
}

\author{
THE BURDEN OF CIVILIZATION: HYSTERIA AND CIVILIZATION \\ IN BRAZILIAN MEDICAL THESES (1838 - 1890)
}

Fernando Marques de Mello Júnior ${ }^{1}$

\begin{abstract}
RESUMO: O desembarque da corte portuguesa em 1808 iniciou um intenso processo de transformações no Rio de Janeiro. Como sede da monarquia, a urbe recebeu investimentos visando à modernização urbana e à europeização dos costumes locais. Segundo a medicina da época, no entanto, esse processo denominado no período de "civilização" poderia trazer aos habitantes, em especial às mulheres, consequências nefastas, dentre elas a histeria. Assim, o estudo visa a mapear o que escreveram os médicos da época a respeito da histeria e de sua relação com a civilização. Para tanto, analisar-se-ão as teses produzidas nas faculdades de medicina do Rio de Janeiro e da Bahia, únicos centros de produção intelectual do gênero no país, entre 1838, ano de defesa da primeira tese versando sobre a histeria, e 1890, quando é publicada a primeira tese a respeito da doença em homens, alterando, ainda que timidamente, o padrão de teses sobre o tema.
\end{abstract}

PALAVRAS-CHAVE: histeria; medicina; processo civilizatório; Brasil oitocentista.

ABSTRACT: The arrival of the Portuguese court in 1808 started an intense process of transformation in Rio de Janeiro. As the capital of the kingdom, the city received investments aimed at urban modernization and at the Europeanization of local customs. According to the medicine at that time, however, such process called "civilization" could bring terrible consequences to the city's inhabitants, especially women - hysteria amongst them. Thus, this study aims to map the writings of medical doctors at the time concerning hysteria and how it is related to civilization. To that end, the present work will analyze the theses produced at the medical schools of Rio de Janeiro and Bahia between 1838 - the year of the first thesis on hysteria - and 1890 - when the

* Este artigo é resultado parcial de pesquisa de doutoramento a ser concluída em 2022, realizada sob orientação do Prof ${ }^{\circ}$. Dro ${ }^{\circ}$. Hélio Rebello Cardoso Júnior.

1 Doutorando em História pelo Programa de Pós-Graduação em História da Universidade Estadual Paulista (UNESP), campus de Assis. E-mail: fernandommellojr@gmail.com 
first thesis mentioning the disease in men was published, which altered, even quite timidly, the patters of theses on the subject.

KEYWORDS: hysteria; medicine; civilizing process; 19th century Brazil.

\section{Introdução}

A arribada de D. João VI na Baía de Guanabara altera profundamente a vida econômica, social e política do Brasil. O Rio de Janeiro, cidade que abrigará o monarca e sua corte, sentirá, com maior intensidade, os efeitos do desembarque da Família Real lusitana e seus nobres seguidores. Ao longo do Oitocentos, a cidade receberá uma série de investimentos visando ao melhoramento sanitário e estrutural da urbe - aterramento de pântanos, novos canais de água, abertura de ruas, entre outros, serão algumas das transformações pelas quais passará a cidade. Ao mesmo tempo, acompanhando a melhoria na estrutura urbana da cidade, a vida social será incrementada com a abertura de cafés, teatros, livrarias e centros comerciais. O desenvolvimento urbano, comercial e de sociabilidade - algo que os coetâneos nomeavam vagamente de civilização -, no entanto, poderia levar, segundo o pensamento médico da época, à diversos males, entre eles a histeria. Assim sendo, o presente artigo visa analisar a relação entre o desenvolvimento urbano e de sociabilidade do Rio de Janeiro e o histerismo. Para tanto, serão analisadas teses de doutoramento que versam sobre o sexo feminino e sobre a histeria produzidas pelos estudantes da Faculdade de Medicina do Rio de Janeiro e da Faculdade de Medicina da Bahia entre os anos de 1838, quando Rodrigo José Maurício Júnior defende sua 'Dissertação sobre a histeria', estudo inaugural acerca do tema no país, e 1890, ano em que Maurillo Tito Nabuco de Abreu publica sua tese intitulada 'Da histeria no homem', primeira tese de doutoramento versando sobre a histeria no sexo masculino, alterando, ainda que timidamente, o padrão discursivo presente nas teses de ambas as faculdades. ${ }^{2}$ Tais monografias,

\footnotetext{
${ }^{2}$ É importante mencionar que, comparando os estudos produzidos em ambas das faculdades, notam-se predominância dos mesmos autores e as mesmas teorias a respeito dos temas desenvolvidos. A semelhança teórica nas teses produzidas no Rio de Janeiro e na Bahia podem
} 
apresentadas como requisito para a conclusão do curso, ainda que não se baseassem em observações empíricas feitas pelos próprios estudantes, sendo antes análises dos principais autores estrangeiros - franceses e ingleses, principalmente -, podem ser consideradas como a materialidade do arcabouço teórico que norteou, em larga medida, a prática dos médicos brasileiros no Oitocentos.

\section{Do processo civilizatório no Rio de Janeiro}

Em 8 de março de 1808, D. João VI e parte da nobreza lusitana desembarcam na baía de Guanabara. A chegada do monarca português ao Rio de Janeiro desencadeou um processo de drásticas transformações na cidade. Administrativamente, a urbe, centro decisório da colônia desde 1763, quando passa a ser a sede do Vice-Reinado, ampliava suas funções políticoburocráticas. No plano econômico, graças à abertura dos portos, o comércio fora impulsionado e a cidade passava a figurar, definitivamente, como um dos mais importantes centros econômicos do país.

As modificações, ocorridas inicialmente na administração e na economia, logo se fizeram sentir também nos traços urbanos da cidade, afinal, como era de se esperar, "a grandeza de uma monarquia americana teria de começar pela grandeza da sua nova capital" (SCHULTZ, 2008, p. 155). Desse modo, os contornos rurais e patriarcais que caracterizaram a cidade durante os tempos coloniais passaram a dar lugar, gradativamente, a paisagens mais urbanas, carregadas de aspectos civilizados e, notadamente, europeus. ${ }^{3}$ Nas ruas, os sobrados recebiam novas fachadas, os caminhos eram calçados com paralelepípedos, a iluminação, a óleo inicialmente e a gás a partir de 1854 ,

ser explicadas, talvez, pelo fato de o programa educacional de ambas as instituições, inauguradas, inclusive, no mesmo ano, ter sido criado pela Sociedade de Medicina do Rio de Janeiro. A documentação consultada se encontra no acervo da Biblioteca Nacional.

${ }^{3}$ Segundo Marieta Pinheira da Carvalho, "civilizar o espaço urbano da cidade do Rio de Janeiro significava, nesse sentido, implementar novas propostas estéticas correlacionadas às vigentes nos países cultos da Europa" (CARVALHO, 2008, p. 103). 
aclarava os passeios públicos, os pântanos eram aterrados e as redes de canais eram reformadas e ampliadas (VERONA, 2013, p. 26).

As transformações ocorridas nos elementos estruturais, arquitetônicos e econômicos da capital fluminense passaram, em pouco tempo, a estimular a até então pacata vida social do Rio de Janeiro e a modificar substancialmente a maneira como o carioca e, em especial, as mulheres da cidade se comportavam socialmente. ${ }^{4}$ Os bailes, os espetáculos musicais, os teatros, os cafés, as livrarias, os bondes puxados a burro e os centros comerciais passaram a movimentar as ruas cariocas, convidando cada vez com maior frequência os habitantes da cidade à diversão e à socialização - esta assaz tímida em tempos coloniais (COSTA, 1989, p. 38).

Assim, ao longo do Oitocentos passa a ser comum aos habitantes do Rio de Janeiro, sobretudo àqueles mais abastados, passeios pelos movimentados centros comerciais, como a Rua do Ouvidor e a Rua da Direita, em busca dos mais variados adornos para o cabelo, tecidos de várias cores e tipos, vestimentas masculinas e femininas ou ainda para um café ou um "gelato" em família (RENAULT, 1984). Frequente, ainda, eram os espetáculos teatrais e líricos no Real Teatro de São João, momentos de comunhão social em que, além da nobreza e dos comerciantes de grosso trato da cidade, compareciam, também, o monarca e sua família. O marchar do século XIX colocou também ao alcance do público letrado da cidade generosa quantidade de títulos literários, seja em formato de livro, seja nos folhetins (NADAF, 2009).

Tamanhas alterações no ambiente urbano e na vida social da capital se fizeram sentir pelos visitantes estrangeiros, muitos dos quais conhecedores dos mais importantes centros europeus e que, graças aos incentivos de D. João VI, começam a se tornar personagens cada vez mais frequentes na paisagem

\footnotetext{
${ }^{4}$ De acordo com Jurandir Freire Costa, a senhora dos tempos coloniais "tornou-se, com a urbanização, uma anacronia. A penetração do capitalismo industrial europeu no Brasil dinamizou a vida social e [...] a vida privada. As 'enclausuradas nas alcovas' tornaram-se 'antifuncionais'. A corte requeria a 'mulher de salão', a 'mulher da rua'. Os grandes negócios e o pequeno comércio exigiam uma e outra, respectivamente. A mulher de posses deveria saber receber as visitas do marido, estar presente à mesa e às conversações. Paralelamente, deveria compenetrar-se de sua nova situação social, abandonando seus antigos hábitos e europeizando seu corpo, seus vestidos e seus modos" (COSTA, 1989, p. 119).
} 
carioca. Assim, frente a tantos prodígios observados durante sua estadia na cidade, Johann Moritz Rugendas não deixa de comentar, em 1835, que:

É em 1808 que começa realmente a história do Brasil e do Rio de Janeiro; e se desde então não houve grandes acontecimentos, vitórias ou derrocadas sangrentas, suscetíveis de atrair para o país a atenção de observadores superficiais, as modificações que ocorreram no estado intelectual e material da antiga colônia, e principalmente da capital, são da mais relevante importância (RUGENDAS, 1974, p. 200).

As modificações sobre as quais discorre brevemente o visitante foram profundamente influenciadas, como era de se esperar, pela civilização do velho continente e dotavam a cidade de características familiares aos visitantes europeus. ${ }^{5}$ Segundo o Príncipe Maximiliano de Wied-Neuwied, curioso aristocrata que, graças à viagem empreendida pelo país entre 1815 e 1817, testemunhou as mudanças ocorridas na nova sede da corte lusitana, "cerca de vinte mil europeus, vindos de Portugal com o rei, se estabeleceram na cidade, daí naturalmente resultando que os costumes do Brasil se modificaram pelos da Europa" (WIED-NEUWIED, 1940, p. 23). Ainda segundo o nobre visitante "melhoramentos de todo o gênero foram realizados na capital. Ela muito perdeu de sua originalidade, tornando-se hoje mais parecida com as cidades europeias" (WIED-NEUWIED, 1940, p. 23). Observação semelhante foi registrada por Carl Friedrich Philipp von Martius e seu compatriota, o naturalista Johann Baptist von Spix, membros da missão artística austro-alemã que visitou o país em 1817:

Quem chega convencido de encontrar esta parte do mundo descoberta só desde três séculos, com a natureza inteiramente rude, violenta e invicta, poder-se-ia julgar, ao menos aqui na capital do Brasil, fora dela, tanto fez a influência da civilização e cultura da velha e educada Europa para remover

\footnotetext{
5 Ainda que o volume de narrativas de viagens exaltando a "europeização" e a "civilização" da sede da corte lusitana na América seja razoável, o número de visitantes que criticaram o Rio de Janeiro por seu suposto atraso em termos civilizatórios não era diminuto - construções, urbanização, modos e cultura receberam considerações estrangeiras pouco elogiosas ao longo do Oitocentos. No entanto, é digno de nota que, ainda que varie o padrão de percepção e apreciação quanto ao estado civilizatório da cidade, tanto os críticos quanto os defensores do suposto progresso civilizatório notaram os incrementos urbanos e a mudança na vida social dos habitantes, fossem eles suficientes e agradáveis - ou não. Sobre as apreciações estrangeiras a respeito da urbanização do Rio de Janeiro: (GAGLIARDO, 2014, p. 157-238).
} 
deste ponto da colônia as características da selvageria americana, e dar-lhe cunho de civilização avançada. Língua, costumes, arquitetura e afluxo de produtos de todas as partes do mundo dão à praça do Rio de Janeiro aspecto europeu (SPIX e MARTIUS, 1981, p. 47).

Além de aprimorar os elementos arquitetônicos e estruturais da cidade e a criar condições para estimular a vida social e intelectual cariocas, o processo civilizatório da cidade, posto em marcha por D. João VI e continuado por seus sucessores, visava "tornar a cidade não apenas esplendorosa, mas também ordeira, decorosa, moral e fiel" (SCHULTZ, 2008, p.194).

Assim, era preciso, acreditava-se, modificar também os hábitos dos moradores da urbe - hábitos esses, assim como os traços urbanos da capital ainda coloniais e, portanto, condizentes a tempos de outrora e distantes do ambiente cortês e civilizado experimentado pelo monarca e sua corte no velho continente - e combater aquilo que os coetâneos denominavam de "desordem das ruas", ou seja, a criminalidade, a vagabundagem e a agitação política, fruto da acelerada urbanização pela qual passou a cidade. Fazia-se necessário, portanto, a criação de instituições e estratégias que agissem no sentido de conhecer e transformar o comportamento da sociedade carioca oitocentista. A instituição médica seria, assim, uma das instituições incumbidas de tão importante empresa.

\section{Da instalação da instituição médica no Rio de Janeiro}

Já em 1808 são adotadas as primeiras medidas visando ao estabelecimento da instância médica no Rio de Janeiro e, consequentemente, à atuação da medicina no processo de ordenação da população local. Preocupado com a saúde dos componentes de sua corte, o Príncipe Regente nomeia, em 2 de abril, poucos dias, portanto, após seu desembarque, Joaquim da Rocha Mazarém como lente de anatomia do Hospital Militar. Na referida instituição, o cirurgião deveria ministrar, além de aulas de anatomia, um curso sobre ligaduras, partos e operações de cirurgia. No ano seguinte, Mazarém é incumbido de ocupar o cargo de professor de medicina operatória e arte 
obstetrícia, dando início, dessa maneira, à Escola Anatômica, Cirúrgica e Médica do Rio de Janeiro. Pouco tempo depois, em 1812, ocorre a fundação da Escola Médico-Cirúrgica, instituição mais bem estruturada para o ensino das artes médicas. Após duas décadas de funcionamento, a Escola MédicoCirúrgica é reestruturada e finalmente transformada, em 1832, em Faculdade de Medicina do Rio de Janeiro, passando a oferecer os cursos de Farmácia, de Medicina e de Partos. O curso de medicina era composto de quatorze matérias, distribuídas ao longo dos seis anos de formação e, além de desempenho satisfatório nas disciplinas componentes do curso, outros requisitos necessários à obtenção do almejado título de doutor incluíam o conhecimento em aritmética, filosofia, geometria, uma língua estrangeira - podendo ser o inglês, o francês ou o latim -, e a defesa em público de uma tese redigida em latim ou em língua vernácula.

Poucos anos antes da criação da Faculdade de Medicina do Rio de Janeiro é fundada na capital a Sociedade de Medicina do Rio de Janeiro, "sem dúvida o grupo mais representativo desse novo estilo de medicina que lutará, de diversas maneiras, para impor-se como guardiã da saúde pública" (MACHADO et. al., 1978, p. 185). Fundada em 1829, a Sociedade de Medicina do Rio de Janeiro "era uma instituição moldada segundo as concepções políticas e teóricas do movimento higienista europeu do final do século XVIII, particularmente o francês" (FERREIRA, et. al., 1997, p. 479), e estaria diretamente relacionada ao processo de institucionalização da higiene no Brasil. Nesse sentido, "a filiação ao higienismo significava a consciência da necessidade de converter a saúde numa questão de interesse público e de competência estatal" (FERREIRA, et. al., 1997, p. 479). Para tanto, seus membros recomendaram ao governo imperial várias disposições administrativas que incorporavam a cidade e sua população ao campo prático do saber médico.

Transformada em Academia Imperial de Medicina em 1834, a instituição seguiu trabalhando arduamente em alguns pontos nevrálgicos para o sucesso do ambicionado projeto higiênico: empenhou-se na regulamentação da profissão, no combate ao 'charlatanismo' dos praticantes não diplomados, no 
trabalho junto às instâncias públicas requerendo autoridade na elaboração das políticas sanitárias do Estado e, também, na publicação de periódicos, livros e traduções relacionadas à medicina (FRANÇA e VIOTTI, 2014, p. 99). Em suma, ocupou-se, a grosso modo, em consolidar a instituição médica, aproximar a medicina do Estado e atuar na ordenação social.

\section{Dos estratagemas da instituição médica}

A criação e a estruturação das associações e instituições de ensino superior marcam o início da investida da medicina sobre a cidade e seus habitantes. Era preciso, no entanto, que a medicina social - essa faceta da medicina que se desenvolverá nessa época no país e que tem por objetivo conhecer e agir sobre o ambiente urbano e sua gente - elaborasse estratégias que possibilitassem sua intervenção no restrito espaço doméstico das famílias cariocas. Adentrar as moradias e medicalizar seus residentes, no entanto, não seria tarefa simples. Isolada em seus domínios e resistentes aos contatos sociais, a família brasileira do início do Oitocentos preferia o recolhimento do lar à confraternização social das ruas. Fazia-se necessário, portanto, adentrar os sobrados patriarcais rompendo, por meio de táticas de natureza positiva, ou seja, mediante o uso de estratégias não coercitivas, sobretudo através da higiene familiar, ${ }^{6}$ a resistência da família patriarcal ao mundo externo e, principalmente, à figura do médico.

Sabe-se que, durante os séculos de domínio metropolitano sobre a colônia, o contingente de médicos atuando nas cidades brasileiras era parco e, em sua maioria, mal formado. Segundo Lycurgo Santos Filho "talvez nem chegassem a 10, em qualquer época dos séculos 16 e 17, os físicos diplomados" (SANTOS FILHO, 1947, p. 50), ou seja, os médicos com formação regular. O minguado número de profissionais de medicina atuando na colônia não foi realidade apenas nos primeiros séculos de domínio lusitano na América. "No

\footnotetext{
${ }^{6}$ Referimo-nos, aqui, ao dispositivo criado pela medicina social com a finalidade de agir sobre a família (COSTA, 1989, p. 79-153).
} 
Rio de Janeiro, sede do Vice-Reinado, residiam quatro físicos em 1789 e, em 1794, eles eram nove", para o desespero do Vice-Rei Luís de Vasconcelos e Sousa. O contingente de cirurgiões no país era igualmente escasso e, não raramente, a maioria tinha de percorrer, assim como os físicos, centenas de léguas para prestar socorro. Em 1783, na cidade de Belém do Pará, por exemplo, além de dois físicos e sete boticários, havia apenas sete cirurgiões aprovados para atender uma freguesia de cerca de 11 mil almas e, na última década do século XVIII, não mais do que "vinte e nove cirurgiões praticavam a cirurgia" em solo carioca (SANTOS FILHO, 1947, p. 50).

Além de insuficientes em número, os médicos, cirurgiões e boticários brasileiros pareciam não possuir conhecimentos satisfatórios para a prática de seus ofícios. Os médicos cariocas, escreve Carl Seidler, eram "em muitos pontos de vista menos sabedores e sempre menos cultos" do que os médicos estrangeiros (SEIDLER, 1980, p.75). John Luccock, comerciante inglês que desembarcou no Rio de Janeiro poucos meses após a chegada de D. João VI, notou o tímido contingente de médicos e cirurgiões formados atuando na cidade e o parco conhecimento de que dispunham, fato que, por vezes, ocasionava procedimentos incrédulos aos menos acostumados. Segundo o viajante,

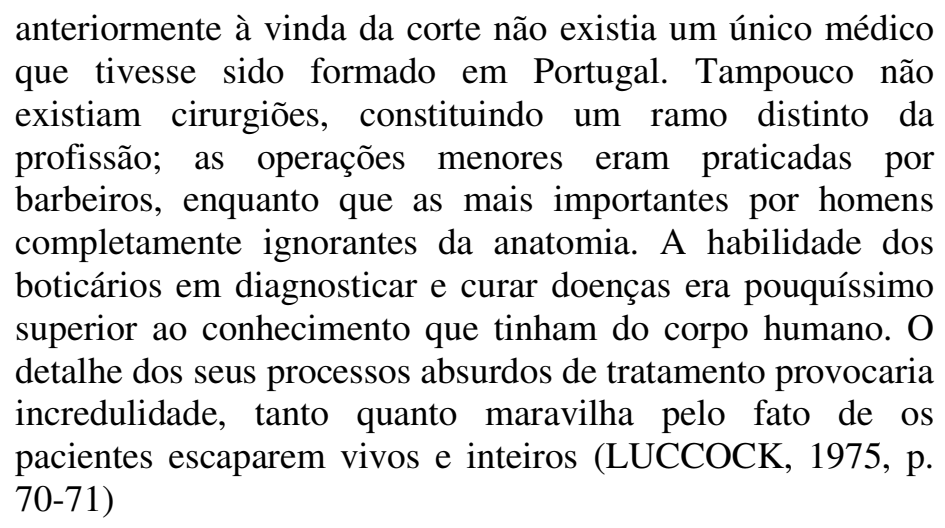

Em virtude da baixa oferta de médicos e cirurgiões diplomados, saídos, mormente, dos bancos da Faculdade de Coimbra, e da desconfiança em relação ao ofício exercido pelos pouco conhecidos doutores, cuja maioria "não valia grande coisa sob o ponto de vista científico e cultural" (SANTOS FILHO, 1947, p. 51), o grosso da população buscava alívio às suas aflições nas mãos de 
indivíduos menos instruídos formalmente, mas que gozavam de maior prestígio social na época, tais como curadores, jesuítas e pajés, além dos barbeiros não examinados e dos “'benzedores', 'rezadores' e 'santos' negros e brancos” (SANTOS FILHO, 1947, p. 148).

Atentas à predileção dos moradores do Rio de Janeiro pelos serviços destes entusiastas da arte de curar em detrimento dos cuidados prestados por médicos diplomados, as instituições médicas brasileiras trabalharam, inicialmente, no sentido de promover a melhora na imagem social da corporação e diminuir, consequentemente, as ressalvas dos cariocas quanto aos cuidados médicos. Para tanto, em primeiro lugar, foi necessário aumentar o contingente de doutores prestando atendimento na cidade para que os habitantes pudessem recorrer aos médicos outorgados quando doentes. Não por acaso, como visto, a instalação de instituições de ensino de medicina começa poucos dias após o desembarque do monarca em terras brasileiras. A fundação das 'Escolas' e da Faculdade de Medicina do Rio de Janeiro visava, desse modo, em um primeiro momento, aumentar consideravelmente o deficitário quadro de médicos atuando na cidade. E, de fato, com a criação das instituições de ensino de medicina na capital fluminense, o contingente de doutores com formação regular e diplomados pelas entidades oficiais passa a aumentar gradativamente. ${ }^{7}$

Além de ampliar a oferta de médicos, era preciso, em segundo lugar, que a academia formasse com maior cuidado os futuros doutores, uma vez que "um profissional bem formado não somente melhor cumpriria as suas delicadas funções, como ainda despertaria nos pacientes uma salutar confiança" (FRANÇA e VIOTTI, 2014, p. 100), melhorando, dessa maneira, a imagem dos médicos perante a sociedade. Em virtude da necessidade de bem formar os estudantes, não causa estranhamento, portanto, o fato de a maior parte do corpo docente da Faculdade de Medicina do Rio de Janeiro ser composta dos "mais conhecidos vultos médicos do período imperial” (HOLANDA, 2004, p. 548).

\footnotetext{
${ }^{7}$ Fabíola Rohden fez um levantamento total de 7.152 trabalhos acadêmicos apresentados à Faculdade de Medicina do Rio de Janeiro entre 1833 e 1940. Ainda que em seu levantamento estejam incluídas, além das teses de doutoramento, teses de livre-docência, de cátedra e de revalidação, o número de estudos sugere o aumento considerável no número de médicos formados (ROHDEN, 2001, p. 111).
} 
As instituições de ensino de medicina contribuíram, desta maneira, para aumentar a oferta de médicos diplomados na cidade e melhorar a qualidade de seus serviços. Tais medidas, conforme planejado pela corporação médica, lograram efeitos positivos na imagem social dos médicos do período, fazendo com que os doutores, de desconhecidos e pouco estimados, passassem a figurar como proeminentes e respeitados personagens na sociedade carioca oitocentista.

Além de garantirem maior prestígio social aos médicos por meio do aumento de profissionais disponíveis e da melhor formação dos mesmos, os dirigentes das entidades de medicina da época perceberam a importância de voltarem suas atenções àqueles que praticavam as artes curativas sem nunca terem frequentado os 'imprescindíveis' bancos das instituições de ensino oficiais. Curadores, sangradores, pajés, parteiras e todos os práticos que, durante o período colonial, trabalharam quase sozinhos na cura dos males da população brasileira, passam a ser, desde então, alvos das instituições médicas cariocas. A Sociedade de Medicina do Rio de Janeiro e seu posterior, a Academia Imperial de Medicina, serão entidades que dedicarão grande parte de seus esforços a combater ferrenhamente o mal do chamado 'charlatanismo'. Em primeiro lugar, o charlatão será visto como obstáculo à defesa da medicina institucionalizada, "por ser um cultor da não-ciência médica, dos sistemas ‘imaginários' ou das ciências não dirigidas pela razão" (MACHADO et. al., 1978, p. 198). Além de escapar à cientificidade e à regulação das academias, universidades e instituições médicas - centros de produção, divulgação e fiscalização da atividade -, esse 'avesso do médico' será perseguido e desacreditado pela corporação em virtude de, segundo a mesma, colocar em perigo a vida da população graças ao falso conhecimento de que dispunham e às torpes práticas utilizadas em seus procedimentos. Justificando o charlatanismo como tema de sua tese, o médico Francisco de Paula Costa toma como necessária a reflexão sobre o assunto, uma vez que a prática era, na época, "uma das causas mais gerais e poderosas da mortandade de nossa nascente população", além de ser geradora de "numerosas moléstias crônicas 
que afligem nossos patrícios e constituem o germe principal de suas misérias físicas" (COSTA, 1841, p. 7). Nota-se, dessa maneira, que ao desprezar os conhecimentos e as práticas não institucionalizadas, a medicina oitocentista gradativamente se isola como guardiã da saúde no país, pois, além de enfraquecer a imagem social dos charlatões, aumenta o contingente de médicos disponíveis e valoriza as qualidades profissionais dos médicos formados.

\section{Da importância da mulher para o projeto civilizatório}

O maior prestígio social dos médicos e a condenação das condutas charlatãs pelas instituições de medicina abriram caminho para o domínio dos doutores sobre a família carioca e possibilitaram a implantação, no ambiente familiar, das práticas médicas. Além do conjunto de críticas dirigidas ao modo de viver da população do Rio de Janeiro - suas residências e seus hábitos eram insalubres e perniciosos, diziam os doutores -, e da ideia de que as relações familiares não medicalizadas seriam prejudiciais aos indivíduos, estratégias que, por si só, já contribuiriam para a convivência com os profissionais de saúde, únicos conhecedores das normas capazes de zelar pelo bem-estar das famílias, os médicos oitocentistas, em especial os higienistas, procuraram penetrar no ambiente familiar por meio de uma relação íntima e inteiramente nova com o sexo feminino. Realocando a posição ocupada pelas mulheres no cotidiano familiar, concedendo-lhes maior autoridade e atribuindo-lhes novas responsabilidades - os papéis reformulados de mãe e de esposa lhes imputariam maiores cuidados em relação à sociabilidade, ao bem-estar do lar e à educação dos filhos ${ }^{8}-$, os médicos oitocentistas ambicionavam ganhar aliadas no interior das residências cariocas, minando possíveis resistências quanto à sua atuação na intimidade do lar e, ao mesmo tempo, aumentar o alcance e a eficácia de suas

\footnotetext{
${ }^{8}$ Durante o Brasil colonial, a educação e o trato das crianças eram feitos frequentemente por terceiros: escravos, parentes próximos e distantes, etc. O governo da casa, também era, muitas vezes, delegado às escravas mais velhas. Assim, o papel das mulheres de posses consistia em encarregar os subordinados para as tarefas do cuidado do lar e da educação das crianças, não havendo, portanto, participação direta nestas funções (FRANÇA, 1990).
} 
ações, uma vez que esposas e mães devidamente instruídas pelos doutores e seu conhecimento instaurariam o regime de vida higiênico para toda a família. ${ }^{9}$

Assim, a senhora colonial deixa o interior da alcova e dá lugar a um novo modelo de mulher, à mulher mãe e esposa, à mulher medicalizada e higiênica - à "mulher cúmplice do médico" (CUNHA, 1986, p. 34-35) -, responsável por trazer harmonia ao espaço doméstico, socializar ao lado do marido e zelar pelos cuidados da educação física e moral dos filhos. Não por acaso, escreve um médico da época que "é como esposa e como mãe que [a mulher] exerce influência salutar sobre a humanidade" (TORRES, 1848, p. 17). Outro doutorando do período reitera o julgamento de seu colega de profissão no que tange à importância do sexo feminino para o pleno desenvolvimento da sociedade. Segundo Tristão Eugenio da Silveira, "na humanidade inteira, a mulher representa, sem dúvida alguma, um importantíssimo papel, debaixo de todos os pontos de vista; como filha, como esposa, como mãe, como amiga, como irmã, é sempre nobre" (SILVEIRA, 1878, p. 3). A coletividade seria, desse modo, devedora dos cuidados despendidos pelas mulheres. Mães, esposas, filhas, irmãs e até mesmo amigas, como evidenciam os doutores, desempenham uma infinidade de papéis fundamentais no interior da família, a pedra angular da sociedade da época. De geradora e educadora das crianças desde os seus primeiros passos a acompanhante do cambaleante esposo no limiar de sua existência, a mulher era colocada pela medicina do período como indispensável à vida familiar e, consequentemente, indispensável também à sociedade. "Como elo de ouro", exemplifica o Dr. Tristão, a mulher "prende as extremidades da grande cadeia social, dirigindo os primeiros passos incertos da criança, e amparando os últimos na marcha vacilante do homem na velhice" (SILVEIRA, 1878, p. 3).

Ainda que o belo sexo desempenhasse várias funções no interior da família, a mais valorosa, reconhecida e louvada socialmente era, sem dúvida alguma, a função de mãe. Como progenitora, a mulher cumpria a dupla função

\footnotetext{
${ }^{9}$ É digno de nota que a mulheres tomadas por objeto das práticas médicas seriam as de famílias mais abastadas, já que seriam estas as mais afetadas pelos efeitos da urbanização e da sociabilidade.
} 
que lhe fora incumbida pela natureza e pela medicina. Em primeiro lugar, satisfazendo um imperativo divino, cumpria "a função mais importante de sua vida”, (COSTA, 1848, p. 21) o sagrado desígnio natural de gerar outro ser e contribuir para a conservação da humanidade. "Tua vida será a vida do gênero humano: a ti, e a ti tão somente, pertence perpetuar a espécie" sintetizará, nesse sentido, um jovem médico (SENA, 1844, p. 15). Em segundo lugar, era investida pela higiene como a responsável pela saúde física e moral da criança e como "o ser superior destinado a preparar o novo ser para a comunhão social" (ABREU, 1890, p. 5). E, essa preparação de que nos fala o Dr. Abreu, deveria começar desde a mais tenra idade. De acordo com o Dr. José Carrão, "entregue até os seis ou sete anos aos cuidados maternos deve o homem encontrar nas palavras da sua mãe a pura verdade" e, em suas sábias ações, "exemplos que sem receio deve seguir no curso da vida" (CARRÃO, 1848, p. 7). Assim, instruída pelos princípios higiênicos, a mulher-mãe voltaria seus esforços para criar homens e mulheres saudáveis, corretos física e moralmente e úteis à sociedade e ao Estado. É nesse sentido que o Dr. Zeferino Justino da Silva Meirelles, dissertando a respeito dos benefícios do aleitamento materno para as crianças, escreve:

Quanto não sois responsável, ó mães, perante a natureza e a sociedade, vós que podeis transmitir com vosso leite nobres e excelentes virtudes e dar à sociedade homens fortes, capazes de suportar todos os trabalhos! Lembrai-vos que nosso futuro, costumes, paixões, gostos, prazeres e até nossa felicidade dependem de vós; corrigi este abuso e os homens tornar-se-ão verdadeiros filhos, maridos e pais; isto feito, uma reforma geral sucederá na sociedade e a natureza reconquistará seus direitos (MEIRELLES, 1847, p. 67).

Devido ao novo status da mulher no ambiente familiar e, principalmente, à sua importância para o funcionamento do projeto higiênico arquitetado pela instância médica e para o progresso da sociedade e perpetuação da espécie - afinal, "a redenção dos homens e da sociedade [estava] em suas mãos”, (NUNES, 2000, p. 67) -, coube aos doutores do período maior atenção no que se refere ao "belo sexo" e a sua saúde. A mulher, escreve em meados do século XIX o médico Luiz Vianna D’Almeida Valle, “deve ser considerada de 
uma maneira minuciosa, atendendo ao sabido grau de importância que se acha revestida" (VALLE, 1847, p. 1). Minúcia que se manifestará no elevado número de escritos médicos produzidos no período e que dão conta dos mais variados aspectos da vida da mulher - o desenvolvimento do corpo e das paixões nas diferentes idades, a gravidez, o parto, o aleitamento, a educação das crianças, os deveres matrimoniais e as principais doenças a que estavam predispostas, passam, assim, a ser objeto de profunda análise médica (ROHDEN, 2001, p. 99).

\section{Da sensibilidade nervosa feminina à histeria}

Nesse contexto de exaustiva reflexão científica a respeito do sexo feminino, uma das tópicas que mais ocupou as páginas dos estudos médicos foi, sem dúvida alguma, a histeria. Doença alocada na categoria das conhecidas 'nevroses' - conceito empregado por Philippe Pinel ${ }^{10}$ e que caracterizava as moléstias do sistema nervoso que não apresentavam lesões orgânicas visíveis -, a histeria afligia os indivíduos impressionáveis, suscetíveis, aqueles dotados de uma constituição nervosa mais sensível.

Destarte, ainda que a enfermidade não fosse apanágio exclusivo da mulher, ${ }^{11}$ esta, possuindo "constituição mais nervosa e mais sensível do que o homem", era considerada pelos médicos do período "mais impressionável, mais apta a receber a ação dos diversos modificadores" (MOURA, 1862, p. 1) e, portanto, mais propensa a desenvolver a enfermidade. A mulher, "cuja cabeça é, as mais das vezes, regida pelo coração" (SANTOS JÚNIOR, 1878, p. 21), conforme anota o Dr. Santos Júnior, reafirmando a sensibilidade feminina, sofreria com maior intensidade as perturbações do sistema nervoso. Dessa maneira,

\footnotetext{
${ }^{10}$ Philippe Pinel (1745-1826) foi um médico francês considerado por muitos o pai da psiquiatria. É autor do clássico Tratado médico-filosófico sobre a alienação mental ou a mania, de 1801.

${ }^{11}$ A possibilidade da histeria no homem dá-se com o deslocamento da sede da doença do útero - condição para a exclusividade da moléstia nas mulheres -, para o cérebro ou para o sistema nervoso (TRILLAT, 1991).
} 
se considerarmos que a constituição física da mulher é mais complicada, impressionável e frágil do que a do homem, e se atendermos ao predomínio das faculdades afetivas no sexo feminino, poderemos asseverar que a histeria é tanto mais frequente na mulher quanto é rara no homem (SANTOS JÚNIOR, 1878, p. 21).

Argumento semelhante pode ser verificado na tese defendida, em 1878, por Tristão Eugenio da Silveira. Segundo o médico, "em virtude de sua organização especial, delicada, fraca, nervosa, da exaltação da sensibilidade e do modo fácil pelo qual sua razão é subordinada às impressões sensitivas [...] é que a histeria é muito mais frequente [na mulher] do que no homem" (SILVEIRA, 1878, p. 14). Em suma, a opinião corrente entre os doutores oitocentistas era que o sexo feminino seria delicado por natureza: seus órgãos e sua estrutura seriam frágeis e suscetíveis aos menores estímulos internos ou externos.

A explicação para a suscetibilidade nervosa verificada nas mulheres e a consequente predisposição feminina ao mal histérico, residiria, de acordo com as teses do período, na constituição de seu próprio sexo e seria, inclusive, condição necessária para a maior aptidão aos seus desígnios naturais e sociais. ${ }^{12}$ De acordo com Antônio Gonsalves de Lima Torres, "a condição natural [da mulher] é ser o coração da família” (TORRES, 1848, p. 10). E, para que ela ocupe com maestria este importante posto social, ela necessita, segundo o doutor,

de um sistema nervoso mais suscetível [...] para poder suportar as dores e os incômodos da maternidade, interessarse por seu filho, consagrar-se toda às ocupações domésticas cuidando do menino, acudindo pressurosa aos incômodos do homem e velando à cabeceira do velho (TORRES, 1848, p. $10)$.

Ou seja, a "sensibilidade, consequência natural de sua organização" (BARROS, 1845, p. 9), nos dizeres de outro médico da época, seria condição

\footnotetext{
${ }^{12}$ Thomas Lacqueur, em Inventando o sexo: corpo e gênero dos gregos a Freud, demonstra que a ideia de dois sexos biológicos distintos provém do final do século XVIII e início do século XIX. Até esse momento, acreditava-se que havia um único sexo biológico e dois gêneros. Nesse modelo explicativo, herdado dos gregos, homens e mulheres não seriam diferentes em termos de natureza, mas em grau de perfeição. O homem, seria o estágio mais alto de perfeição enquanto a mulher, em termos naturais, seria um homem imperfeito. (LAQUEUR, 2001).
} 
para que a mulher desenvolvesse a afetividade, qualidade essencial para o desempenho das funções para as quais a natureza ${ }^{13}$ a destinou: a saber, as obrigações matrimoniais, domésticas e maternas. ${ }^{14}$

A sensibilidade feminina, portanto, estaria rigorosamente relacionada à sua própria natureza, aos aspectos constitutivos e particulares de seu corpo. Nesse sentido, José Joaquim Ferreira Monteiro de Barros, explicando fisiologicamente a sensibilidade observável no sexo feminino, anota que "a polpa cerebral partilha da moleza das outras partes [do corpo da mulher] e a vitalidade do sistema nervoso é [por isso] elevada ao mais alto grau" (BARROS, 1845, p. 5). De acordo com o médico, diplomado em 1845, "esta circunstância explica bem claramente a esquisita sensibilidade deste sexo: a vivacidade e, ao mesmo tempo, a extrema mobilidade de todas as suas sensações, tanto internas quanto externas" (BARROS, 1845, p. 5). Devido à sensibilidade constitutiva do corpo feminino e à relação existente entre impressionabilidade do sistema nervoso e histerismo, não causa surpresa, portanto, a opinião corrente entre os médicos oitocentistas a respeito da predominância da doença entre as mulheres. Diante dos inúmeros casos da moléstia nervosa entre senhoras e senhoritas, o Dr. Rodrigo José Gonsalves alerta, em 1848, que "é a histeria tão frequente nas mulheres que [...] é preciso, em geral, suspeitá-la nelas, como se suspeitam os vermes nos meninos, e a sífilis nos adultos" (GONSALVES, 1846, p. 3).

\footnotetext{
${ }^{13}$ A referência à natureza como criadora dos seres e suas particularidades é uma constante nas teses médicas do período. No entanto, é bom frisar, o vago termo parece possuir, nessa época, conotação religiosa. Assim, em 1848, o Dr. José Luiz da Costa, em uma tese a respeito sobre o amor medicamente considerado, anota no rodapé de seu trabalho que "a palavra natureza tem para nós o valor daquilo que não podemos explicar; ou é para nós sinônimo de Criador, Deus, etc" (COSTA, 1848, p. 6).

${ }^{14}$ Tal premissa possibilita isentar a sociedade pela definição dos papeis sociais desempenhados pelos sexos. Em virtude da constatação de que é a constituição física da mulher a produtora de sua sensibilidade, particularidade que designa as mulheres aos deveres matrimoniais, maternais e sociais, os médicos da época conseguiam, ao mesmo tempo, isentar o corpo social pelos lugares ocupados por homens e mulheres na sociedade e dotar de caráter natural tais atribuições sociais. A igualdade de direitos entre os sexos, pleiteada por alguns na época, seria, segundo essa concepção, uma aberração social e antinatural, pois contrariaria a vontade da natureza e colocaria em equidade fisiologias e funções sociais claramente desiguais. A esse respeito, ver: (COSTA, 1848, p. 26).
} 


\section{Da civilização como causa da histeria}

Em tempos em que o Rio de Janeiro passava por profundas transformações urbanas e sociais, a 'suspeita' dos doutores deveria ser intensificada, uma vez que, segundo as observações médicas, os progressos da "civilização" e as novas demandas sociais atribuídas ao sexo feminino com a transformação da "mulher enclausurada" em "mulher de salão" pareciam favorecer manifestações da temível doença.

De acordo com o médico baiano Cid Emiliano, "todas as influências, quer físicas, quer morais, exercidas sobre o [ser humano], tem uma ação mais ou menos pronunciada sobre o seu sistema nervoso" (CARDOZO, 1857, p. 5). Nesse sentido, "as modificações trazidas ao estado social pela civilização não são despidas de uma influência qualquer sobre o desenvolvimento das afecções nervosas" (CARDOZO, 1857, p. 5). Não causa espanto, portanto, a incidência da enfermidade entre as habitantes dos grandes centros urbanos brasileiros. Salvador, cidade natal do Dr. Emiliano e, principalmente, o Rio de Janeiro, sede da corte e localidade onde os progressos sociais e urbanos eram sentidos a olhos vistos, tenderiam a produzir maior número de histéricas do que em cidades menores ou na vida fo campo, uma vez que, de acordo com o médico, ocorrerá "frequência maior de afecções nervosas [...] onde a civilização apresentar maior desenvolvimento" (CARDOZO, 1857, p. 6). Os grandes centros urbanos seriam, dessa maneira, locais privilegiados para o aparecimento de histéricas graças aos mais variados estímulos disponíveis à população - não por acaso, explica um médico, "já chamaram a histeria a endêmica dos grandes povoados". (MOURA, 1862, p. 13). A histeria, escreve o Dr. Maurillo de Abreu,

é uma nevrose que acompanha 'invariavelmente' os progressos da civilização em relação à sua maior frequência e constância. Nos grandes centros, com efeito, se acham todos os elementos que debilitam a organização e que fazem predominar o sistema nervoso e todas as condições que podem influenciar a parte afetiva deste sistema. Daí o fato de existirem maior número de casos de histeria nas grandes capitais, onde a civilização se evoluciona progressivamente (ABREU, 1890, p. 13. Aspas minhas) 
A histeria seria, portanto, aos olhos a medicina, uma espécie de ônus do processo civilizatório, uma de suas consequências indesejadas. $\mathrm{O}$ bombardeio de estímulos de toda a ordem trazidos pelo progresso e pela urbanização da cidade, atuando sobre os indivíduos de constituições nervosas delicadas, em especial das mulheres, desencadearia o nefasto mal do histerismo.

A utilização de perfumes, por exemplo, deveria ser, sempre que possível, preterida pelos cariocas devido a atuação das variadas fragrâncias sobre o sistema nervoso. "'Os cheiros atacam os nervos'. Este velho axioma, conhecido do vulgo, é sancionado pela ciência”, sentencia o Dr. Cid Emiliano. De fato, continua o médico, "quaisquer que sejam os cheiros, [estes] exercem sobre o sistema nervoso uma influência manifesta que varia, é verdade, com a natureza deles" (CARDOZO, 1857, p. 10). Desse modo,

se alguns aromas penetrantes especiais exercem, em geral, sobre o cérebro [...] uma ação ligeiramente estimulante, que torna mais fácil o exercício intelectual, afugenta o sono e exalta certos sentimentos, outros muitos, ou estes mesmo usados sem moderação, levam esta exaltação ao excesso ou produzem efeitos de outra ordem, profundamente pernicioso (CARDOZO, 1857, p. 10)

Ainda que, segundo o julgamento do médico, não sejam todas as fragrâncias nocivas ao sistema nervoso, "muitas pessoas há, e mormente do sexo feminino, cuja excitabilidade nervosa exalta-se excessivamente pela presença de um aroma qualquer, a ponto de serem imediatamente atacadas de síncopes, de histeria, ou de qualquer outra afecção do mesmo gênero" (CARDOZO, 1857, p. 5). Diante de tantos inconvenientes provocados, principalmente às mulheres, pela utilização de perfumes, o Dr. Cid Emiliano indaga a respeito da quantidade de prejuízos determinados pela utilização indiscriminada das estimadas fragrâncias:

esta imensidade de perfumarias e de cosméticos, tão variados em sua confeição, que aí andam livremente pelo comércio, fazendo o objeto da especulação mercantil de tantos Pivers, e o precioso sine quo dos moços casquilhos e das jovens loureiras, como outrora o foram da célebre Cleópatra, a rainha libidinosa e devassa, de quantos e quão profundos males não tem sido causa? (CARDOZO, 1857, p. 10-11) 
A música, esta "admirável e encantadora linguagem dos anjos" (CARDOZO, 1857, p. 12), na opinião de Cid Emiliano, deveria ser apreciada, de maneira semelhante à perfumaria, com moderação e prudência pelos seus diletantes, em especial por aqueles do sexo feminino. "Além da ação que fisicamente exerce sobre o sistema nervoso pelas impressões que, recebidas pelo nervo acústico, a todo ele são transmitidas", escreve o médico, a música "tem sobre o espírito uma influência enérgica que se revela poderosamente pelos fenômenos nervosos" (CARDOZO, 1857, p. 12). Quem é, interroga retoricamente o doutor,

que ouvindo tocado por uma orquestra marcial o expressivo
hino nacional, não sente ferver-lhe a cabeça, o coração e a
economia inteira ao fogo do entusiasmo que lhe abrasa o
espírito? Quem é que ouvindo a harmonia quase divina do
stabat mater não sente no fundo d'alma as mais vivas
emoções? Quem é que não se sente abatido ao peso da mais
grave melancolia ao ouvir executar-se uma peça
expressivamente fúnebre? (CARDOZO, 1857, p. 12)

Desse modo, prossegue Cid Emiliano, a música provoca "o sentimento que ela exprime e, assim, exalta ou deprime o sistema nervoso, podendo, por isso, dar lugar a manifestações de nevroses diversas" (CARDOZO, 1857, p. 12). Logo, não deve causar surpresa ao leitor o caso descrito pelo médico de uma "senhora que, apenas ouvindo o som de um violão, ou de outro qualquer instrumento, é imediatamente atacada de histeria, que só em tais casos se manifesta" (CARDOZO, 1857, p. 13).

As doenças nervosas e, em especial, o histerismo, eram também estimuladas pelo teatro, gênero artístico que, com a chegada do monarca e sua corte ao Rio de Janeiro, passa a entreter cada vez mais os moradores da cidade. "Os espetáculos dramáticos, tão modificados ao marchar da civilização e, cuja utilidade realmente civilizadora é de lastimar, têm uma influência manifesta e poderosa sobre o sistema nervoso, exaltando a imaginação e despertando os sentimentos", explica o médico baiano. "Ninguém de certo deixará de ter sentido, assistindo a um espetáculo cheio de cenas tocantes e trágicas", argumenta Cid, "paixões de diversas naturezas, sempre excitadas pelas impressões causadas pelas ações que se representam no cenário" (CARDOZO, 
1857, p. 13). Estas paixões, estimuladas pelas cenas representadas nos tablados e que "abalam profundamente o sistema nervoso, são muitas vezes causas de nevroses de vários gêneros, mormente nas senhoras, que, tendo nascido mais para sentir do que para pensar, têm o sistema nervoso muito mais excitável ou impressionável" (CARDOZO, 1857, p. 13).

Os muitíssimo apreciados bailes foram também matéria de preocupação dos vários doutores do século XIX em virtude dos múltiplos estímulos sensoriais que o compõem. "Estas escolas de desmoralização e parto abortivo de uma civilização desmandada", conforme escreve energicamente o Dr. Cid Emiliano, cuja atmosfera seria composta pelos "sons arrebatadores da música", pelo "perfume inebriante das flores", pelos vertiginosos rodopios "de uma valsa imoral", pelos "diálogos indecentes" e por muitos outros estimulantes, "obrando quase diretamente sobre o sistema nervoso, produzem quase inevitavelmente o longo catálogo de moléstias que lhe são próprias" (CARDOZO, 1857, p. 13).

No entanto, uma das causas da histeria mais comentadas pelos homens de medicina do período foi, de acordo com suas teses acadêmicas, a leitura dos muito estimados - e, na opinião médica, perigosos - romances ou novelas. ${ }^{15}$ Conforme explica o Dr. Constantino Luis da Silva Moura, de todas as causas produtoras da histeria "a mais comum e a mais caprichosa é, talvez, a leitura de romances" (MOURA, 1862, p. 12). Percorrer detidamente por longas horas as páginas "de obras licenciosas e de romances é um péssimo recurso que, de ordinário, procuram as mulheres para desenfado de suas fadigas", escreve o Dr. Monteiro de Barros. "Além de estragarem o moral e de corrompê-lo", explica o médico, "o romance tem o inconveniente de exagerar certos sentimentos pela pintura viva de grandes rasgos de heroísmo e de paixões" (BARROS, 1845, p. 30). Desse modo, questiona:

se as pessoas sensatas, acostumadas a ver as coisas debaixo de um ponto de vista justo, razoável e exato, sentem muitas vezes fortes emoções com semelhantes leituras, o que não deverá suceder a uma mulher fraca e sensível que por um

\footnotetext{
${ }^{15}$ Ainda que existam diferenças entre os dois gêneros literários, parece que, na época, ambos se confundiam e se referiam às narrativas ficcionais.
} 
instinto natural já é propensa a tudo exagerar? (BARROS, 1845, p. 30)

A influência dos romances sobre a frágil constituição nervosa feminina era tamanha, segundo os doutores oitocentistas, que era cantilena entre os médicos do período o aforismo escrito pelo célebre Samuel Tissot ${ }^{16}$ no século XVIII e que afirmava categoricamente que "toda moça que aos 15 anos lê romances, aos 20 torna-se nervosa" (SILVEIRA, 1878, p. 70).

Vê-se, portanto, que, de acordo com as teorias médicas em voga no Oitocentos, "todas as excitações continuadas dos bailes, dos teatros, das leituras apaixonadas", enfim, toda a vida daquilo que, na época, denominava-se “o grande mundo, [ou seja, a civilização], favorecem e determinam o aparecimento da histeria" (CORRÊA, 1878, p. 12).

\section{Da predisposição}

Ainda que raramente terminasse por ceifar a vida da doente, a moléstia proporcionava às enfermas uma existência plena de desconfortos: convulsões gerais, espasmos, nevralgias, alucinações, modificações comportamentais e morais severas, crises de choro, anestesias, confusões mentais, problemas digestivos, perturbações de motilidade, distúrbios de sono, entre muitos outros incômodos e dores, atormentavam regularmente as histéricas. Para amenizar essa longa série de tormentos, o médico oitocentista poderia lançar mão da vasta gama de fármacos conhecidos na época.

Embora dificilmente se conseguisse o completo reestabelecimento da doente, o tratamento medicamentoso visava controlar a crises e abrandar o sofrimento das histéricas. "O tratamento curativo", explica o Dr. Santos Júnior, “propõe[-se] a fazer a histeria desaparecer". Porém, em virtude da sabida dificuldade em debelar a doença, "quando o resultado não pode ser obtido, [o tratamento] visa a diminuir ou moderar os fenômenos mais penosos".

\footnotetext{
${ }^{16}$ Samuel Auguste André David Tissot (1728-1797) foi um médico neurologista francês. Sua obra mais conhecida é Aviso ao povo acerca da sua saúde datada de 1773.
} 
(SANTOS JÚNIOR, 1878, p. 72). O Dr. Horácio Corrêa sugere, como parte do tratamento paliativo, por exemplo, "a poção anti-histérica do Codex, as gotas calmantes alemãs, o elixir fétido de Fulde, o carminativo de Dalby e a tintura valeriana amoniacal de Ph. Lond" (CORRÊA, 1878, p. 46). Já o Dr. Joaquim Sena recomendava às suas pacientes, além dos "antiespoamódicos, antiflogísticos, revulsivos e tônicos", fármacos amplamente utilizados no tratamento da histeria e das crises nervosas, os célebres narcóticos. De acordo com o médico, "o ácido hidrociano medicinal na dose d'uma a duas gotas em uma onça d'água tem produzido ótimos resultados" (SENA, 1844, p. 24) e, ainda segundo Sena, o médico francês "Bichat diz ter curado três jovens histéricas por meio da injeção na vagina de 100 a 150 gotas de láudano" (SENA, 1844, p. 23).

Antiespasmódicos, revulsivos, tônicos e narcóticos atenuavam os sofrimentos das acometidas de histerismo. No entanto, os efeitos perniciosos da doença não se limitariam apenas à própria doente. "Raras vezes mortal", explica o Dr. Couto dos Santos Júnior, a histeria, "condena as doentes a uma vida desagradável e incômoda" não somente para si mesmas, mas, também, "para as pessoas que as cercam, em razão das desordens que produz no organismo" (SANTOS JÚNIOR, 1878, p. 67). Pais, esposos e, principalmente, os filhos seriam afetados diretamente pela doença, uma vez que a histeria, além de castigar fisicamente filhas, esposas e mães, limitava a vida social das doentes, impedindo-as de frequentar a sociedade ao lado do esposo, e prejudicavam a regência doméstica e a educação dos filhos.

Contudo, se, conforme anota o Dr. Santos Júnior, as enfermas e seus entes próximos padeciam diretamente dos inúmeros inconvenientes provocados pela doença, as consequências se revelavam mais danosas à família, enquanto instituição, e à sociedade. Não raras vezes, escreve o Dr. Moura, a doença conduzia as mulheres ao caminho do desregramento moral, das perversões sexuais, da masturbação, do amor lésbico, da prostituição e da insanidade mental, incapacitando-as, portanto, aos "deveres da família e da sociedade", 
(MOURA, 1862, p. 21) ou, em outros termos, às obrigações sociais de esposa e de mãe.

Além de inviabilizar o projeto higiênico ao impedir o desenvolvimento de mulheres saudáveis, aptas a desempenharem magistralmente os papeis de mãe, de guardiã da casa e de companheira do esposo, a histeria poderia comprometer a disposição física, mental e moral das futuras gerações por meio do princípio da hereditariedade. ${ }^{17}$ De acordo com o pensamento médico da época - largamente influenciado pela teoria da degeneração de BenedictAugustin Morel $^{18}$-, a histeria reservava aos filhos das doentes, os futuros cidadãos do país, grande probabilidade de, ao longo de sua existência, padecerem de um sem número de enfermidades físicas e nervosas (CAPONI, 2012, p. 85). Segundo o Dr. Tristão Eugenio da Silveira, todos os médicos estariam de perfeito acordo ao afirmar que "os filhos herdam as predisposições ingênitas ou adquiridas dos pais, e isso tanto em relação ao físico como ao moral e, como às moléstias, as quais, muitas vezes, são o único bem legado pelos pais" (SILVEIRA, 1878, p. 13). Destarte, pontua o médico, a mãe histérica comunica a seu filho a 'predisposição' a desenvolver, "sujeito a qualquer das causas determinantes" (SILVEIRA, 1878, p. 13), ou seja, uma leitura licenciosa, uma música excitante, um espetáculo estimulante, um odor instigante, por exemplo, a histeria. Teoria defendida quase nos mesmos termos por Joaquim Sena, em 1844: "assim como herdamos a fisionomia de nossos pais, seu caráter, seus costumes e mesmo sua inteligência”, explica o médico, "também herdamos disposições para, nas mesmas circunstâncias, adquirirmos moléstias de que eles foram vítimas" (SILVEIRA, 1878, p. 13). Seguindo essa

\footnotetext{
17 A estratégia ligada à hereditariedade tinha uma função importante na psiquiatria que se formava: conferir à doença mental um corpo não encontrado em lesões físicas, fundamento da medicina moderna. Segundo Foucault, "já que não se pode e não se sabe como encontrar no doente um substrato orgânico para sua doença, trata-se então de encontrar no nível da sua família certo número de acontecimentos patológicos que serão tais que, qualquer que seja aliás sua natureza, eles se referirão à comunicação e, por conseguinte, à existência de certo substrato material patológico" (FOUCAULT, 2006, p. 352).

${ }^{18}$ Benedict-Augustin Morel (1809-1873) foi um influente médico conhecido por seus trabalhos sobre alienação mental. É autor do clássico Tratado das degenerescências na espécie humana, publicado em 1857, livro em que o médico desenvolve a teoria da degeneração, possivelmente sua ideia mais conhecida.
} 
lógica determinista, portanto, parece razoável ao Dr. Sena que "uma mulher que tiver sido vítima de ataques histéricos repetidos e por muito tempo, vindo a ter filhos, estes podem herdar estas disposições para, nas mesmas circunstâncias, e, mais facilmente, serem atacados da mesma moléstia” (SENA, 1844, p. 16).

\section{Da educação enquanto profilaxia}

Frente a cenário tão temerário à família e, consequentemente, a todo o corpo social e à nação, cabia aos doutores da época erradicar a enfermidade antes de sua manifestação. O tratamento paliativo, ainda que moderasse o sofrimento das pacientes e de seus entes quando dos frequentes ataques, não seria, contudo, o mais indicado, pois agiria em um organismo já debilitado e marcado com a herança maldita. De acordo com o pensamento médico do período, em virtude da dificuldade em se tratar a enfermidade depois de seu aparecimento e, sobretudo em razão do problema da 'transmissão' de males aos filhos, mais proveitoso seria ao indivíduo, e principalmente à sociedade, o tratamento profilático, ou seja, o tratamento preventivo, posto que tal intervenção abrangeria "não só a vida atual do indivíduo, mas, a sua existência anterior, representada nos pais" (CORRÊA, 1878, p. 43).

Desse modo, o tratamento deveria, conforme assevera o Dr. Constantino Moura, "começar antes do nascimento", visando, assim, erradicar o mal antes de sua manifestação e preservar as futuras gerações da predisposição não somente à histeria, mas a uma ampla variedade de males físicos e, principalmente, morais. "É nos preceitos da higiene e em sua aplicação à educação física e moral que consiste", de acordo com o médico, "a verdadeira profilaxia" capaz de evitar com eficácia o mal histérico. E, anotando a importância do tratamento preservativo para as próximas gerações, o Dr. Moura explicita que "se quiserdes meninos robustos, convém primeiramente tornar os pais robustos" (MOURA, 1862, p. 25).

Dentre os meios profiláticos mais indicados pelos médicos oitocentistas para robustecer os corpos das genitoras e reduzir, substancialmente, a marcha 
da histeria no corpo social, a educação, como já adiantou o Dr. Constantino Moura, ocupava lugar de destaque. Esta, escreve seu colega, o Dr. Corrêa, "quando bem dirigida, constitui o meio profilático mais eficaz para debelar a predisposição histérica". Todavia, complementa, "se viciosamente encaminhada, prepara o organismo por tal forma que a eclosão mórbida é inevitável" (CORRÊA, 1878, p. 13).

Vê-se, portanto, que a educação "bem dirigida", conduzida, obviamente, pelos "valiosos meios que a higiene e a medicina ministram" (CORRÊA, 1878, p. 45), conforme atenta o médico, poderia preparar as delicadas jovens cariocas para enfrentar os efeitos da civilização sem sofrerem do histerismo. Nesse sentido, de acordo com outro profissional da época, o Dr. Seixas, "para prevenir e sustar a continuação dessa enfermidade é [dever] do médico velar na educação física e moral do sexo feminino", tendo por intento "fortificar-lhe a constituição física, regularizar as funções da economia, afastar as causas que podem desarranjá-la", além, é claro, de se ocupar em "acalmar e moderar a sensibilidade, os sentidos e a imaginação" das doentes (SEIXAS, 1851, p. 1415). Baseado em tais princípios, amplamente divulgados nas teses médicas do período, o Dr. Horácio Corrêa explica que é preciso cuidar para que haja, além da habitação no campo, medida capaz de afastar as mulheres dos contínuos estímulos da civilização, a "abstenção de atos que possam trazer emoções de qualquer espécie, como a leitura de obras próprias para exaltar a imaginação e as paixões, a frequentação dos teatros, dos bailes, dos concertos", entre outros (CORRÊA, 1878, p. 55). Seguindo a mesma linha, o Dr. Attaíde Moncorvo prescreve detalhadamente como deveria ser conduzida a educação das meninas:

Em lugar das leituras licenciosas dos romances da escola moderna, em que as paixões são representadas no seu mais alto grau de exageração, da frequência dos bailes e teatros que estragam a sua sensibilidade, suscitando desejos incompatíveis com sua idade, e exaltando sua fraca imaginação; e da música e da pintura que tão somente devem ser por elas estudadas como meio de desenfado e como diversão dos trabalhos domésticos, devem-se-lhes procurar distrações fortes, sociedades agradáveis, afastando-as da solidão como meios capazes de enfraquecer o aguilhão da voluptuosidade (MONCORVO, 1848, p. 6). 
Dever-se-ia, deste modo, complementa o Dr. Moura, "dirigir toda a atividade moral e intelectual das jovens para ocupações que [afastassem] delas a ociosidade, o tédio, a melancolia, as ilusões e todas as emoções factícias" (MOURA, 1862, p. 27) - ou seja, emoções artificiais, "criadas por necessidades que não estão ligadas à conservação e reprodução da vida" (MACHADO et al., 1878, p. 413) e que se afastam, forçosamente, dos deveres de esposa e mãe.

Ora, como vimos anteriormente, o Rio de Janeiro oitocentista proporcionava aos seus habitantes uma infinidade de divertimentos que, segundo as teorias médicas vigentes, abalavam o sistema nervoso das mulheres e as desviavam de sua missão social. Os contumazes bailes, os espetáculos teatrais, as reuniões sociais embaladas ao som da viola ou do piano, a disponibilidade de romances e a oferta de fragrâncias e perfumes faziam parte da vida dos cariocas e podiam, dependendo da constituição do indivíduo, desregrar seu sistema nervoso e, consequentemente, debelar a histeria. Além disso, tais costumes sociais ditos 'civilizados' poderiam concorrer para dirigir as mulheres aos prazeres e divertimentos mundanos, conduzindo-as ao desregramento moral e ao abandono de seus papéis em sociedade.

Não bastasse os perigos colocados à sociedade pela urbanização e pela civilização, a educação, meio fortemente capaz de impedir o aparecimento da moléstia nervosa, parecia, na época, não ser empreendida de maneira acertada e vigilante pelo Estado e pelos pais. No Brasil, segundo o julgamento do Dr. Maurillo de Abreu, “o assunto de educação só nestes últimos tempos tem começado a preocupar o espírito nacional” (ABREU,1890, p. 13). Essa negligência no que se refere à educação dos jovens, em especial das mulheres, além de não assegurar sua saúde, poderia, ao contrário, favorecer manifestações de histeria na população. "A influência que a educação tem na produção da histeria é de suma importância. Ela, por si só, constitui uma de suas causas mais importantes", escreve o Dr. Maurillo (ABREU, 1890, p. 13). Se implementada corretamente, como visto anteriormente, a educação poderia robustecer o sistema nervoso das jovens, além, é claro, de afastar delas as causas que perturbavam sua economia. No entanto, se empreendida de maneira inadequada 
e viciosa, a educação poderia, ao contrário, tornar "o sistema nervoso muitíssimo impressionável e predisposto à manifestação da nevrose histérica" (ABREU, 1890, p. 13).

O Dr. Sena, em sua 'Dissertação sobre a histeria' exemplifica aos seus leitores a educação de uma jovem malconduzida pela mãe. Seguindo outros médicos do período em suas censuras aos males decorrentes da civilização e à educação dos jovens, o doutorando explica que, “apesar de ter a civilização atual tocado seu Zenith de perfeição, a vida que se leva nas grandes cidades e cortes e a educação, máxime do belo sexo, não deixam de ser assaz repreensíveis" (SENA, 1844, p. 3). Em virtude disso, uma mãe de um grande centro urbano qualquer, já vítima de uma educação falha e corrompida, "experimenta grande desgosto vendo sua filha, ainda em tenra idade, não manifestar já grande vivacidade" e tendência à sociabilidade do mundo civilizado. Diante disso,

em vez de acostumá-la aos trabalhos da agulha, [...] o mais forte de todos os poderes reunidos na terra para sopear as paixões, ao contrário, lhe facilita o estudo da música e pintura e a leitura de livros os mais próprios a excitar sua sensibilidade, nutrindo, assim, o espírito de sua filha com ilusões e ideias contrárias ao estado real da sociedade (SENA, 1844, p. 3).

A tudo isso, continua, acrescente-se, ainda,

as modas que o luxo acarreta, a frequentação de sociedades numerosas, bailes, teatros, etc. e nisto cifra-se toda a educação e ocupam a pobre menina que, no meio destas circunstâncias, perde a tranquilidade e a paz de seu coração, sua sensibilidade exalta-se e, tornando-se ardente sua imaginação, as vistas da natureza são iludidas e ela é acometida de convulsões (SENA, 1844, p. 3).

A educação da mulher deveria ser trabalhada com maior esmero na época da puberdade, período em que, segundo o Dr. Oliveira, "se manifesta a grande função catamenial, em que todo o organismo se expande, o coração se abre a todos os sentimentos afetivos, e a imaginação se exalta, alimentada por excitantes de toda a sorte" (OLIVEIRA, 1878, p. 20). Nesse período crítico, em que a jovem, em razão das transformações do corpo, se torna mais sensível, 
“dever-se-á proibir tudo o que puder alimentar a imaginação e a exaltá-la, como a leitura de romances, os bailes, os teatros, a poesia, o estudo exclusivo das belas artes, da música e da pintura" (OLIVEIRA, 1878, p. 20).

Apoiando-se em uma rígida educação de cunho religioso e moral, amparada nas "verdades fundamentais da doutrina cristã" e nas "boas obras moralistas" (SILVEIRA, 1878, p. 70) - sugestão frequente, inclusive, às leitoras dos apreciados romances -, os médicos visavam a robustecer o corpo e, sobretudo, o espírito das jovens, para que as futuras esposas/mães não sucumbissem aos estímulos da civilização.

\section{Considerações finais}

A análise dos escritos médicos produzidos ao longo do século XIX sugere que o processo civilizatório do Rio de Janeiro, ainda que proveitoso aos habitantes em virtude de implementar na cidade importantes transformações econômicas, urbanísticas, intelectuais e, principalmente, de sociabilidade, poderia acarretar o aumento de casos de histeria entre a população local. Com a chegada de D. João e de parte da nobreza lusitana à cidade, a população, além de gozar dos benefícios do calçamento e iluminação dos passeios públicos, da reforma e ampliação das redes de canais e de maior oferta de transporte com os bondes puxados a burros, foi agraciada, também, com o incremento ou a criação de novas casas teatrais, cafés, livrarias e centros comerciais que, como era de se esperar, convidava o carioca, em especial o mais abastado, aos divertimentos fora de casa e à comunhão social.

As mudanças que ocorriam na cidade, no entanto, apesar de benéficas aos cariocas e à corte, preocupavam a nascente instância médica brasileira que se articulava e que buscava maior espaço para gerir a cidade e sua gente. Assim, os doutores do período, em sintonia com as principais teorias médicas da Europa, viam na urbanização e na sociabilidade nascente riscos à saúde da população carioca. A preocupação se dava em virtude de haver, segundo o pensamento médico da época, relação entre os estímulos gerados pelo progresso 
daquilo que os coetâneos denominavam vagamente de "civilização" - a urbanização e a grande oferta de produtos de moda, beleza, distrações literárias e de espetáculos musicais e teatrais - e doenças mentais. Ou seja, o convívio dos moradores com os abarrotados centros comerciais, os dramas, tragédias e os espetáculos líricos encenados nas casas teatrais, ou ainda os apreciados romances, disponíveis em armazéns, livrarias e folhetins, poderia produzir, em certos indivíduos, manifestações de doenças mentais. Dessa maneira, os indivíduos dotados de constituição frágil e sensível, em especial o sexo feminino, naturalmente constituído para sentir mais do que pensar, sofreriam com maior intensidade as ações produzidas pelos avanços da "civilização" no Rio de Janeiro e sofreriam, mais frequentemente, com diversas doenças mentais e nevroses, como a histeria. Companheira indesejável das sensações produzidas no sistema nervoso por bailes, espetáculos musicais, peças de teatro, música e leitura de romances, em suma, por estímulos de elementos "civilizados" e que, se não foram postos em cena pela chegada do monarca à cidade, ganharam maior destaque no desde o seu desembarque, a histeria preocupava os doutores cariocas menos em virtude dos inconvenientes causados às doentes do que pelos impactos na saúde da população. Além de impedir as mulheres de desenvolverem plenamente as funções de mãe e esposa, a doença poderia prejudicar as futuras gerações devido à sua capacidade de degenerar a progenitura, o futuro da nação que se formava.

No que tange ao sexo masculino, o histerismo apareceria em homens com menor frequência do que nas mulheres. A histeria masculina, de maneira semelhante à feminina, estaria também relacionada à questão da sensibilidade. Os diagnósticos da moléstia nos homens se devem, segundo alguns médicos do período, à sua criação afeminada. De acordo com Couto dos Santos Júnior, “os fatos excepcionais de histeria no homem [...] são em geral devidos à educação afeminada que recebem grande número de meninos" (SANTOS JUNIOR, 1878, p. 22). Essa "educação afeminada" de que fala o médico, atuando no organismo masculino, torná-lo-ia mais sensível do que o normal e, portanto, propenso a desenvolver a doença. Ou seja, mesmo nos casos de histeria em homens, a 
questão da feminilidade estaria posta - na educação pouco masculina e na consequente sensibilidade feminina. A histeria masculina, portanto, parece ser a manifestação de uma doença feminina em um organismo masculino feminilizado por práticas pedagógicas inadequadas. Além disso, a histeria em homens preocupava em menor grau os médicos da época. Isso porque a doença, quando manifestada em indivíduos do sexo masculino, pouco afetava o funcionamento da família higiênica. Se a histérica era a antítese da mãe burguesa, o avesso da mulher medicalizada e higiênica e, portanto, a impossibilidade de materialização da mãe e da esposa medicamente consideradas, o homem, ainda que doente, poderia exercer suas funções sociais sem maiores prejuízos à família higiênica.

A alternativa mais eficiente para combater a inevitável influência dos progressos urbanos e da sociabilidade cortesã sobre os moradores do Rio de Janeiro, em especial, sobre as cariocas, dada sua importância social, consistia, de acordo com o pensamento médico do período, em assegurar uma rígida e bem dirigida educação física e moral da população. Deste modo, a instituição médica da época, fortalecendo sua posição como guardiã da saúde coletiva, se encarregará de instaurar um regime de vida baseado nos ensinamentos da higiene e de prescrever um sem-número de normas de conduta visando não apenas o robustecimento do físico e moral dos indivíduos, mas, também, o afastamento das causas produtoras do histerismo do sexo feminino.

\section{Referências}

CARVALHO, Marieta Pinheiro de. Uma ideia ilustrada de cidade: as transformações urbanas no Rio de Janeiro de D. João VI: (1808 - 1821). Rio de Janeiro: Odisséia, 2008.

CAPONI, Sandra. Loucos e degenerados: uma genealogia da psiquiatria ampliada. Rio de Janeiro: Fiocruz, 2012.

COSTA, Jurandir Freire. Ordem Médica e Norma Familiar. Rio de Janeiro: Graal, 1989.

Paulo: Escuta, 1995.

A face e o verso - Estudos sobre o homoerotismo II. São 
CUNHA, Maria Clementina Pereira. O espelho do mundo - Juquehy, a história de um asilo. Rio de Janeiro: Paz e Terra, 1986.

FERREIRA, Luiz Otávio; MAIO, Marcos Chor; AZEVEDO, Nara. A Sociedade de Medicina e Cirurgia do Rio de Janeiro: a gênese de uma rede institucional alternativa. Hist. cienc. saúde-Manguinhos, Rio de Janeiro, v. 4, n. 3, p. 475-491, Nov. 1997

FOUCAULT, Michel. O poder psiquiátrico. São Paulo: Martins Fontes, 2006.

FRANÇA, Jean Marcel Carvalho. Literatura e sociedade no Rio de Janeiro oitocentista. Lisboa: Imprensa Nacional-Casa da Moeda, 1999.

A higienização do povo: medicina social e alienismo no Rio de Janeiro oitocentista. Dissertação (Mestrado em Sociologia) - Faculdade de Filosofia e Ciências Humanas, Universidade Federal de Minas Gerais, Belo Horizonte, 1990.

; VIOTTI, Ana Carolina de Carvalho. Das relações com o corpo no Brasil. In: RODRIGUES, Cristina; LUCA, Tania; GUIMARÃES, Valéria (Org.). Identidades brasileiras: composições e recomposições. São Paulo: Cultura Acadêmica, 2014.

GAGLIARDO, Vinicius Cranek. Uma Paris dos trópicos?: Perspectivas da europeização do Rio de Janeiro oitocentista. São Paulo: Alameda, 2014.

HOLANDA, Sérgio Buarque de (Dir.). O Brasil Monárquico: reações e transações. Coleção História geral da civilização brasileira. Tomo II. vol. 3. $8^{\mathrm{a}}$ ed. Rio de Janeiro: Bertrand Brasil, 2004.

LAQUEUR, Thomas Walter. Inventando o sexo: corpo e gênero dos gregos a Freud. Rio de Janeiro: Relume Dumará, 2001.

MACHADO, Roberto (et. al.). Danação da Norma: Medicina Social e Construção da Psiquiatria no Brasil. Rio de Janeiro: Edições Graal, 1978.

MAINENTE, Renato Aurélio. Reformar os Costumes ou Servir o Público: visões sobre o teatro no Rio de Janeiro oitocentista. Tese (Doutorado em História) - Faculdade de Ciências Humanas de Sociais, Universidade Estadual Paulista “Júlio de Mesquita Filho", Franca, 2016.

MATTOS, Ilmar Rohloff de. O tempo saquarema. São Paulo: Hucitec, 1987.

NADAF, Yasmin Jamil. O romance-folhetim francês no Brasil: um percurso histórico. Letras, Santa Maria (RS), Universidade Federal de Santa Maria, v. 19, n. 2, jul.-dez. 2009, p. 119-138. 
NUNES, Silvia Alexim. O corpo do diabo entre a cruz e a caldeirinha: um estudo sobre a mulher, o masoquismo e a feminilidade. Rio de Janeiro: Civilização Brasileira, 2000.

RENAULT, Delso. O Rio antigo nos anúncios de jornais: 1808-1850. Rio de Janeiro: Francisco Alves, 1984.

ROHDEN, Fabíola. Uma ciência da diferença: sexo e gênero na medicina da mulher. Rio de Janeiro: Fiocruz, 2001.

SANTOS FILHO, Lycurgo de Castro. História da Medicina no Brasil: do século XVI ao século XIX. São Paulo, Brasiliense, 1947, 2 Tomos.

SCHULTZ, Kristen. Versalhes Tropical: império, monarquia e a Corte real portuguesa no Rio de Janeiro, 1808-1821. Rio de Janeiro: Civilização Brasileira, 2008.

TRILLAT, Etienne. História da Histeria. São Paulo: Escuta, 1991.

VERONA, Elisa Maria. Da feminilidade oitocentista. São Paulo: Editora UNESP, 2013.

Fontes:

ABREU, Maurillo Tito Nabuco de. Da histeria no homem. Tese apresentada à Faculdade de Medicina do Rio de Janeiro, 1890.

BARROS, José Joaquim Ferreira Monteiro. Considerações Gerais sobre a Mulher, e sua Diferença do Homem e sobre o Regime que deve seguir no Estado de Prenhes. Tese apresentada à Faculdade de Medicina do Rio de Janeiro, 1845.

CARRÃO, José Marianno de Amorim. Algumas considerações sobre o homem nas suas diferentes idades. Tese apresentada à Faculdade de Medicina do Rio de Janeiro, 1848.

CARDOZO, Cid Emiliano de Olinda. Influência da civilização sobre o desenvolvimento das afecções nervosas. Tese apresentada à Faculdade de Medicina da Bahia, 1857.

CORRÊA, Horácio. Histeria. Tese apresentada à Faculdade de Medicina do Rio de Janeiro, 1878.

COSTA, Francisco de Paula. Algumas reflexões sobre o charlatanismo. Tese apresentada à Faculdade de Medicina do Rio de Janeiro, 1841. 
COSTA, José Luiz da. Considerações sobre o amor. Tese apresentada à Faculdade de Medicina do Rio de Janeiro, 1848.

EBOLI, Thomaz. Dissertação sobre a higiene, os prejuízos que causam uma má amamentação. Tese apresentada à Faculdade de Medicina do Rio de Janeiro, 1880.

GAMA ROZA, Francisco Luiz da. Higiene do casamento. Rio de Janeiro: Tipografia de G. Leuzinger, 1876.

GONSALVES, Rodrigo José. Dissertação sobre a Histeria. Tese apresentada à Faculdade de Medicina do Rio de Janeiro, 1846.

LUCCOCK, John. Notas sobre o Rio de Janeiro e partes meridionais do Brasil. Belo Horizonte: Editora Itatiaia Limitada/ São Paulo: EDUSP, 1975.

MEIRELLES, Zeferino Justino da Silva. Breves considerações sobre as vantagens do aleitamento materno. Tese apresentada à Faculdade de Medicina do Rio de Janeiro, 1847.

MONCORVO, Laurindo Marques de Attaide. Algumas considerações higiênicas e médico-legais sobre o casamento e seus casos de nulidade. Tese apresentada a Faculdade de Medicina do Rio de Janeiro, 1848.

MOURA, Constantino L. da Silva. Histeria. Tese apresentada à Faculdade de Medicina da Bahia, 1862.

OLIVEIRA, Manoel Francisco de. Histeria. Tese apresentada à Faculdade de Medicina do Rio de Janeiro, 1878.

RUGENDAS, João Maurício. Viagem pitoresca através do Brasil. Belo Horizonte: Editora Itatiaia Limitada/ São Paulo: EDUSP, 1974.

SANTOS JUNIOR, Miguel Couto dos. Histeria. Tese apresentada à Faculdade de Medicina do Rio de Janeiro, 1878.

SEIXAS, Antonio Luiz de Sousa. Dissertação sobre a histeria. Tese apresentada à Faculdade de Medicina da Bahia, 1851.

SENA, Joaquim Antão de. Dissertação sobre a histeria. Tese apesentada à Faculdade de Medicina do Rio de Janeiro, 1844.

SILVEIRA, Tristão Eugenio da. Histeria. Tese apresentada à Faculdade de Medicina do Rio de Janeiro, 1878. 
SPIX, Johann Baptiste von; MARTIUS, Carl Friedrich Philipp von. Viagem pelo Brasil. Vol. I. Belo Horizonte: Editora Itatiaia Limitada/ São Paulo: EDUSP, 1981.

TORRES, Antônio Gonçalves de Lima. Breves considerações sobre o físico e o moral da mulher nas diferentes fases da sua vida. Tese apresentada à Faculdade de Medicina do Rio de Janeiro, 1848.

VALLE Luiz Vianna D'Almeida. Mulher e matrimônio medicamente considerados. Tese apresentada à Faculdade de Medicina do Rio de Janeiro, 1847.

WIED-NEUWIED, Maximiliano de. Viagem ao Brasil nos anos de 1815 a 1817. São Paulo: Companhia Editora Nacional, 1940.

Recebido em: 15 de maio de 2020

Aceito em: 19 de julho de 2021 